\title{
Pouteria ramiflora extract inhibits salivary amylolytic activity and decreases glycemic level in mice
}

\author{
NEIRE M. DE GOUVEIA ${ }^{1}$, CIBELE L. DE ALBUQUERQUE ${ }^{1}$, \\ LAILA S. ESPINDOLA ${ }^{2}$ and FOUED S. ESPINDOLA ${ }^{1}$ \\ ${ }^{1}$ Instituto de Genética e Bioquímica, Universidade Federal de Uberlândia, Uberlândia, \\ Laboratório de Bioquímica e Biologia Molecular, Campus Umuarama, Bloco 2E, Sala 235, 38400-902 Uberlândia, MG, Brasil \\ ${ }^{2}$ Universidade de Brasília, Faculdade de Ciências da Saúde, Laboratório de Farmacognosia, \\ Campus Universitário Darcy Ribeiro, Asa Norte, 70910-900 Brasilia, DF, Brasil
}

Manuscript received on June 27, 2012; accepted for publication on February 27, 2013

\begin{abstract}
In this study, extracts of plant species from the Cerrado biome were assessed in order to find potential inhibitors of human salivary alpha-amylase. The plants were collected and extracts were obtained from leaves, bark, and roots. We performed a preliminary phytochemical analysis and a screening for salivar alpha-amylase inhibitory activity. Only three botanical families (Sapotaceae, Sapindaceae and Flacourtiaceae) and 16 extracts showed a substantial inhibition (>75\%) of alpha-amylase. The ethanolic extracts of Pouteria ramiflora obtained from stem barks and root barks decreased amylolytic activity above $95 \%$ at a final concentration of $20 \mu \mathrm{g} / \mathrm{mL}$. Thus, adult male Swiss mice were treated orally with P. ramiflora in acute toxicity and glycemic control studies. Daily administration with 25,50 and $100 \mathrm{mg} / \mathrm{kg}$ of aqueous extract of $P$. ramiflora for eight days can reduce significantly body weight and blood glucose level in mice. These data suggest that the crude polar extract of $P$. ramiflora decreases salivary amylolytic activity while lowering the blood levels of glucose.
\end{abstract}

Key words: alpha-amylase inhibition, hypoglycemia, Pouteria ramiflora, Sapotaceae.

\section{INTRODUCTION}

Recently, several studies of alpha-amylase inhibition have been conducted with the aim of discovering new potential drugs capable of reducing postprandial hyperglycemia that could be used in the treatment of diabetes mellitus type 2 and obesity. Inhibitors of this enzyme reduce postprandial hyperglycemia by delaying carbohydrate digestion and decrease intestinal glucose absorption (Ali et al. 2006, Funke and Melzig 2006, Gad et al. 2006, Kim et

Correspondence to: Foued Salmen Espindola

E-mail: foued@ufu.br al. 2005, Shu et al. 2009). Plants continue to play an important role in the treatment of diabetes, particularly in developing countries (Marles and Farnsworth 1994, Oliveira et al. 2005). Medicinal plants from the Cerrado biome has been previously investigated by bioprospection (de Mesquita et al. 2009, Flausino et al. 2009, Mesquita et al. 2005, Napolitano et al. 2005, Rodrigues et al. 2006). However, few studies have investigated the biological activity of such medicinal plants extracts or their isolated components on the activity of alpha-amylase (Silva et al. 2007, 2009). 
Inhibition studies of alpha-amylase activity by natural products have been performed in vitro using human pancreatic alpha-amylase (HPA) (Ali et al. 2006, Conforti et al. 2005, Gad et al. 2006). Alternatively, as human salivary alpha-amylase $(\alpha-1,4-D$-glucan-4-glucanohydrolases, EC 3.2.1.1, HSA) is highly homologous to HPA, and both proteins adopt very similar structures (Brayer et al. 1995, Ramasubbu et al. 2003), the use of HSA as an experimental model for in vitro inhibition studies with natural products has the advantage of saliva being ease and not invasive to collect. Previous studies have shown similar in vitro inhibition of HPA and HSA activities (Kim et al. 2005, McDougall et al. 2005).

The aims of this study are (1) to screen selected plants extracts from the Brazilian Cerrado for possible HSA inhibitory activity, and (2) to carry out a biological assay in mice to investigate any effects on glycemic and toxicity of the stem bark extract from Pouteria ramiflora (Mart.) Radlk.

\section{MATERIALS AND METHODS}

Collection AND Preparation of the Plants For SCREENING

The plants were collected in the Cerrado biome, in the outskirts of Brasilia, Distrito Federal, Brazil, and were identified at the Department of Vegetable Anatomy, Institute of Biology, Universidade de Brasília (UnB). The voucher specimens were deposited in the Herbarium of UnB. Extracts were obtained from leaves, wood bark, stem bark and roots of the selected plants. Air-dried and powdered plant material were successively extracted with hexane and ethanol $95 \%$ by maceration. Crude extracts were obtained after evaporation of the solvents under reduced pressure at $40^{\circ} \mathrm{C}$. Extracts were dissolved in dimethylsulfoxide (DMSO) (Sigma-Aldrich, Saint Louis, USA) at a concentration of $10 \mathrm{mg} / \mathrm{mL}$. Stock solutions of each extract were prepared before experiments.
Samples were stored at $-20^{\circ} \mathrm{C}$ until analysis. Plant species investigated, part used, solvent and voucher numbers are presented in Table I.

COllection AND PREPARATION OF THE POUTERIA RAMIFLORA EXTRACT FOR IN VIVO ASSAY

Stem barks of $P$. ramiflora were collected in the Cerrado biome in the outskirts of Uberlândia, Minas Gerais, Brazil. The plant was botanically identified at the Institute of Biology, Universidade Federal de Uberlândia, and placed in the herbarium of the same institution (voucher specimen, HUFU, 45,535). The vegetables were dried at $37^{\circ} \mathrm{C}$ and then grounded in an electric mill. Aqueous solution of P. ramiflora (PrSBAE) was used for the extraction process that lasted eight days. After extraction, the solution was filtered and lyophilized. Extract was then solubilized in water for in vitro studies.

\section{PRELIMINARY TLC AND HPLC PHYTOCHEMICAL ANALYSIS}

The TLC analysis was carried out using 60G silica gel plates (10 x $10 \mathrm{~cm} ; 0.25 \mathrm{~mm}$; Aldrich), eluted with BAW (n-butanol:acetic acid:water, 4:1:5, upper phase) or $\mathrm{CHCl} 3: \mathrm{MeOH}(8: 2)$ and stained with NP/PEG (natural products - polyethylene glycol reagent) and vanillin-sulphuric acid reagent in separated plates. All extracts were also analyzed in analytical HPLC (Shimadzu, Kyoto, Japan) with SupelcosilTM LC-18 column $(250$ x $4.6 \mathrm{~mm}$; Supelco) and PDA detector. The mobile phase consisted of $0.1 \%$ aqueous acetic acid and methanol with a flow rate of $1 \mathrm{~mL} / \mathrm{min}$. The mobile phase composition began with $10 \%$ methanol, followed by linear increase of $66 \%$ in $32 \mathrm{~min}$ and returned to the initial condition in $35 \mathrm{~min}$ for the next run.

SCREENING FOR ALPHA-AMYLASE INHIBITIORY ACTIVITY

Alpha-amylase inhibition was performed using a commercial kit (Kit Analisa - Belo Horizonte, Minas Gerais, Brazil) based on starch-iodine color changes (Caraway 1959). Saliva was collected from nine individuals using a modified 
method (Navazesh 1993). The pooled saliva was centrifuged at $14,000 \mathrm{xg}$ for $15 \mathrm{~min}$ at $4^{\circ} \mathrm{C}$. The supernatant was diluted $(500 x)$ in phosphate buffered saline, $\mathrm{pH}$ 7.4. Extracts $(10 \mathrm{mg} / \mathrm{mL})$ were pre-incubated with the diluted saliva supernatant for $4 \mathrm{~min} 35 \mathrm{sec}$ at $37^{\circ} \mathrm{C}$. The final concentration of the plant extract in the incubation was $200 \mu \mathrm{g} / \mathrm{mL}$. The reaction was started by addition of $10 \mu \mathrm{L}$ of the supernatant solution in $250 \mu \mathrm{L}$ of starch solution. The tubes were incubated at $37^{\circ} \mathrm{C}$ for $7 \mathrm{~min} 30 \mathrm{sec}$. The reaction was stopped by the addition of iodine. This assay was also carried out with acarbose (10 $\mathrm{mg} / \mathrm{mL}$ ) (provided by EMS S/A, São Paulo, Brazil) - a drug therapeutically used as alpha-glucosidase and alpha-amylase inhibitor (positive control). The final concentration of acarbose was $200 \mu \mathrm{g} / \mathrm{mL}$. DMSO was used as a negative control $(10 \mu \mathrm{L})$. The final concentration of the negative control in the incubation was $0.022 \mu \mathrm{g} / \mathrm{mL}$.

The inhibition of the activity of HSA was expressed as a percentage in which alpha-amylase activity of the non-incubated saliva supernatant was considered $100 \%$. Extracts that presented the highest inhibition rates were selected for a subsequent inhibitory assay at lower concentrations. For the secondary assay, the same method described before was used with increasing final concentration of the extract $(20,50$ and $100 \mu \mathrm{g} / \mathrm{mL})$ incubated with the diluted saliva supernatant.

ANIMALS

Healthy adult male Swiss mice aged 7-8 weeks (weigh: 25-30g) were used for this study. Animals were housed under standard conditions $\left(25^{\circ} \mathrm{C}, 12 \mathrm{~h}\right.$ light and $12 \mathrm{~h}$ dark cycle) and fed with rat chow and water ad libitum. All procedures for handling, use and euthanasia of these animals followed carefully the resolutions proposed by the Brazilian Society of Science in Laboratory Animals and were approved by the Ethics Committee in Animal Research of the Universidade Federal de Uberlândia, Brazil (CEUA/UFU 060/10).
ACUTE TOXICITY STUDY

Experiments were carried out as previously described (Brito 1994). In the acute toxicity study, animals were treated orally and by intraperitoneal injection with PrSBAE extract. Mice were given PrSBAE at doses of 50,500 and $5,000 \mathrm{mg} / \mathrm{kg}$ daily for a period of 18 days $(n=5)$. Animals were observed for $2 \mathrm{~h}$ continuously and then hourly for $8 \mathrm{~h}$, and finally after every $24 \mathrm{~h}$ up to 18 days for any physical signs of toxicity such as writhing, hypnosis, dyspnea or mortality.

EFFECTS OF THE PRSBAE EXTRACT ON THE LEVELS OF BLOOD GLYCAEMIA

Twenty mice were divided randomly in four groups and treated orally for eight days in the following manner: Group 1 (water, control), 2 (25 mg/ $\mathrm{kg}$ of PrSBAE), 3 (50 mg/kg of PrSBAE), and 4 (100 $\mathrm{mg} / \mathrm{kg}$ of PrSBAE). Treatments were administrated in the same time, once a day, in alternate days. After the eighth day, mice were fasted overnight (for $8 \mathrm{~h}$ ) and then were weighed and sacrificed. Glycemic level in blood serum was measured by a colorimetric enzymatic method (Labtest, Minas Gerais, Brazil).

STATISTICAL ANALYSIS

Statistical comparisons were made using one-way ANOVA followed by the Tukey test. $p$-values lower than 0.05 were considered statistically significant.

\section{RESULTS AND DISCUSSION}

One hundred and nine crude extracts were tested, of which 47 were ethanolic and 52 hexanic. In the initial screening, all extracts were prepared as hexanic and ethanolic crude extracts from different parts of 17 plant species belonging to six botanical families (Flacourtiaceae, Sapindaceae, Sapotaceae, Bignoniaceae, Asteraceae and Apocynaceae) (Table I). The percentages of inhibition of the HSA by the most effective extracts are shown in Table II. Only 16 extracts from six species belonging to the 
botanical families, Sapotaceae, Flacourtiaceae and Sapindaceae, were found to have an inhibitory effect on HSA activity (greater than $75 \%$ ), including four ethanolic extracts obtained from root bark, root wood and stem bark of P. ramiflora. The extracts were more effective to inhibit the activity of alpha-amylase in vitro than acarbose in the same concentration $(200 \mu \mathrm{g} / \mathrm{mL})$. We observed that ethanolic extracts presented more effective HSA inhibition activity than hexanic extracts. This result was also reported in other studies of HSA inhibition activity with plant extracts of different families from the Cerrado biome (de Souza et al. 2012, Silva et al. 2009).

Preliminary qualitative phytochemical analysis of the active extracts was performed to determine the probable type of compounds present in the extracts causing HSA inhibition. We visualize by TLC the components of only few extracts. Flavonoids were found in the ethanolic extract of the P. torta leaves and hexane extract of the $P$. ramiflora stem bark. Tannins and saponins were found in the ethanolic extract of the Serjania lethalis stem bark and root bark, and ethanolic extracts of the $P$. ramiflora root wood. Tannins were found in the ethanolic extracts of the $P$. ramiflora root bark. As we observed, previous studies have reported that the capacity of alpha-amylase inhibition by vegetal extracts is normally associated with polar compounds, as phenolic, tannins and triterpenoids compounds (Ali et al. 2006, Gad et al. 2006, Kandra et al. 2004).

The extracts that showed the highest inhibition in the screening test at a concentration of $200 \mu \mathrm{g} / \mathrm{mL}$ were subsequently investigated at concentrations of 100, 50 and $20 \mu \mathrm{g} / \mathrm{mL}$. The S. lethalis stem wood

TABLE I

Family, plant species investigated, part used/solvent and voucher number.

\begin{tabular}{|c|c|c|c|}
\hline Family & Species & Part used/sovent & Voucher \\
\hline \multirow{3}{*}{ Apocynaceae } & Aspidosperma macrocarpa Woodson & SW (E, H); SB (E, H); RW (E); RB (E, H); L (E) & (UB) 3692 \\
\hline & Himatantus obovatus (M. Arg) Woodson & $\mathrm{RB}(\mathrm{H}) ; \mathrm{L}(\mathrm{H})$ & (UB) 3678 \\
\hline & $\begin{array}{l}\text { Hancornia pubescens (Nees \& Mart.) M. } \\
\text { Arg. }\end{array}$ & L (H); RW (H); RB (H) & (UB) 3677 \\
\hline Asteraceae & Piptocarpha rotundifolia (Less.) Baker & RW (E, H); L (E, H); RB (E, H); SB (H); SW (E) & (UB) 3676 \\
\hline \multirow{3}{*}{ Bignoniaceae } & $\begin{array}{l}\text { Tabebuia caraiba (Silva Manso) Benth. \& } \\
\text { Hook.f ex S. Moore }\end{array}$ & $\begin{array}{l}\text { RB (E); SB (H); L (E, H); SW (E, H); SB (E); RB } \\
(\mathrm{H}) ; \mathrm{RW}(\mathrm{E})\end{array}$ & (UB) 3701 \\
\hline & Anemopaegma arvense (Vell.) Stellf. & L (E, H); S (H); R (E, H); FS (E, H); S (E) & (UB) 3691 \\
\hline & Cybistax antisyphilitica (Mart.) Mart. & WS (E, H); L (E, H); SW (E, H); SB (E, H); & (UB) 3696 \\
\hline \multirow[t]{2}{*}{ Flacourtiaceae } & $\begin{array}{l}\text { Casearia sylvestris SW. var. lingua } \\
\text { (Camb.) Eichl. }\end{array}$ & $\begin{array}{l}\text { SW (E, H); RB (E, H); SB (E, H); RW (H); R (E); L } \\
(\mathrm{E}, \mathrm{H})\end{array}$ & (UB) 3693 \\
\hline & Piptocarpha macropoda (DC.) Baker & $\mathrm{SB}(\mathrm{H}) ; \mathrm{L}(\mathrm{H})$ & (UB) 3708 \\
\hline \multirow{4}{*}{ Sapindaceae } & Cupania vernalis Cambess & $\begin{array}{l}\text { SB }(E, H) ; R B(E, H) ; R W(H) ; S W(E, H) ; L(E, H) ; \\
\text { R (E) }\end{array}$ & (UB) 3695 \\
\hline & Matayba guianensis Aubl. & SB (E, H);SW (E, H); RB (E, H) & (UB) 3697 \\
\hline & Serjania lethalis A.St.Hil. & L (E, H); SW (E, H); SB (E, H); RB (E, H) & \\
\hline & Magonia pubescens A. St.Hill. & $\mathrm{L}(\mathrm{H}) ; \mathrm{SB}(\mathrm{H})$ & (UB) 3702 \\
\hline \multirow{4}{*}{ Sapotaceae } & Chrysophyllum soboliferum Rizzini & $\mathrm{L}(\mathrm{E}, \mathrm{H})$ & (UB) 3733 \\
\hline & Pouteria ramiflora (Mart.) Radlk & L (E, H);RB (E, H); SW (E, H); RW (E); SB (E, H) & (UB) 3671 \\
\hline & Pouteria gardnerii (Mart. \& Miq.) Baehni & $\mathrm{L}(\mathrm{E}, \mathrm{H})$ & (UB) 3672) \\
\hline & Pouteria torta Radlk. & $\mathrm{L}(\mathrm{E}, \mathrm{H})$ & (UB) 3674 \\
\hline
\end{tabular}

Part used: L, leaf; SW, stem wood; SB, stem bark; RW, root wood; RB, root bark; R, root; FS, fruit+seed; S, stem (bark+wood); WS, wood+stem bark. Extraction solvent: H, hexane; E, ethanol. 
ethanolic extract and stem bark ethanolic extract (20 $\mu \mathrm{g} / \mathrm{mL}$ ) inhibited almost $40 \%$ of the HSA activity. The ethanolic extracts $(20 \mu \mathrm{g} / \mathrm{mL})$ of Matayba guianenses and $S$. lethalis root bark and $P$. torta leaves inhibited $70-80 \%$ of the HSA activity. Ethanolic extract of the $P$. ramiflora root bark and hexane extract of the P. ramiflora stem bark $(20 \mu \mathrm{g} / \mathrm{mL})$ showed a $95-100 \%$ of inhibition effect, respectively. Studies from the bark of $P$. caimito reveal the presence of the triterpenes (Ardon and Nakano 1973, Pellicciari et al. 1972). Seven polyphenolic compounds, gallic acid, (+)-gallocatechin, (+)-catechin, (-)-epicatechin, dihydromyricetin, (+)-catechin-3-O-gallate, and myricitrin, were isolated and identified from the fresh fruits of $P$. campechiana, P. sapota and $P$. viridis (Ma et al. 2004). These reports indicate that the capacity of alpha-amylase inhibition by genus Pouteria might be associated with such compounds.

We selected the stem bark aqueous extract of P. ramiflora (PrSBAE) for in vivo studies because it inhibited $92 \%$ of the HSA activity when it was diluted $1 / 10$. In the acute toxicity test, mice treated with PrSBAE extract in doses higher than $500 \mathrm{mg} /$ $\mathrm{kg}$ showed toxicity signals as hypnoses, dyspnea,

TABLE II

Plant species investigated, part used/solvent, yields in terms of dry starting material and percentage of inhibitory activity of crude extracts on human salivary alpha-amylase.

\begin{tabular}{|c|c|c|c|}
\hline Species & Part used/sovent & Yield (\%) & Inhibition (\%) \\
\hline \multirow{5}{*}{ Cupania vernalis Cambess } & $\mathrm{L}(\mathrm{H})$ & 7.82 & $57 \pm 50.1$ \\
\hline & SW (E) & 3.78 & $63 \pm 55.3$ \\
\hline & $\mathrm{RB}(\mathrm{E})$ & - & $94 \pm 5.6$ \\
\hline & $\mathrm{SB}(\mathrm{E})$ & 6.15 & $82 \pm 16.0$ \\
\hline & $\mathrm{R}(\mathrm{E})$ & - & $81 \pm 21.9$ \\
\hline \multirow{2}{*}{ Matayba guianensis Aubl. } & SB (E) & - & $79 \pm 0.0$ \\
\hline & $\mathrm{RB}(\mathrm{E})$ & - & $86 \pm 9.1$ \\
\hline \multirow{5}{*}{ Serjania lethalis A.St.Hil. } & $\mathrm{SB}(\mathrm{H})$ & 0.34 & $92 \pm 6.8$ \\
\hline & $\mathrm{SB}(\mathrm{E})$ & 3.20 & $98 \pm 1.5$ \\
\hline & SW (E) & 9.74 & $92 \pm 3.5$ \\
\hline & $\mathrm{RB}(\mathrm{H})$ & 0.46 & $66 \pm 14.0$ \\
\hline & $\mathrm{RB}(\mathrm{E})$ & 2.56 & $89 \pm 1.4$ \\
\hline \multirow{5}{*}{ Casearia sylvestris SW. var. lingua (Camb.) Eichl. } & $\mathrm{RB}(\mathrm{H})$ & 2.25 & $58 \pm 50.9$ \\
\hline & $\mathrm{RB}(\mathrm{E})$ & 4.23 & $68 \pm 31.3$ \\
\hline & SB (E) & 14.97 & $90 \pm 5.8$ \\
\hline & $\mathrm{SW}(\mathrm{E})$ & 11.02 & $87 \pm 5.2$ \\
\hline & $\mathrm{L}(\mathrm{H})$ & - & $36 \pm 27.1$ \\
\hline \multirow{5}{*}{ Pouteria ramiflora (Mart.) Radlk } & $\mathrm{L}(\mathrm{E})$ & 4.84 & $61 \pm 42.5$ \\
\hline & $\mathrm{RB}(\mathrm{E})$ & 8.65 & $96 \pm 4.9$ \\
\hline & RW (E) & 3.62 & $97 \pm 4.6$ \\
\hline & $\mathrm{SB}(\mathrm{E})$ & - & $77 \pm 19.9$ \\
\hline & $\mathrm{SW}(\mathrm{H})$ & 5.98 & $83 \pm 15.3$ \\
\hline Pouteria torta Radlk. & $\mathrm{L}(\mathrm{E})$ & 5.08 & $77 \pm 6.7$ \\
\hline acarbose (positive control) & - & - & $58 \pm 2.8$ \\
\hline DMSO (negative control) & - & - & $0 \pm 4.7$ \\
\hline
\end{tabular}

Part used: L, leaf; SW, stem wood; SB, stem bark; RW, root wood; RB, root bark. Extraction solvent: H, hexane; E, ethanol. Results are represented as means of replicates \pm S.D. 


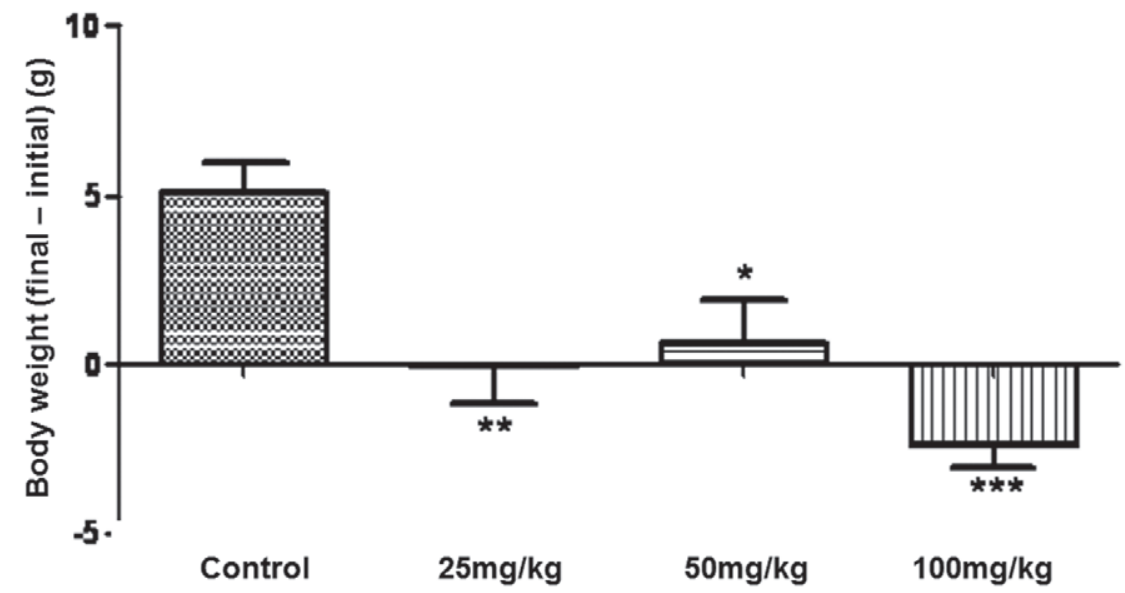

Figure 1 - The effect of administration of stem bark aqueous extract from P. ramiflora (PrSBAE) for eigth days on body weight loss in mice. Each column represents mean \pm S.E.M for five mice. $* P<0.05, * * P<0.01, * * * P<0.001$ different from control group.

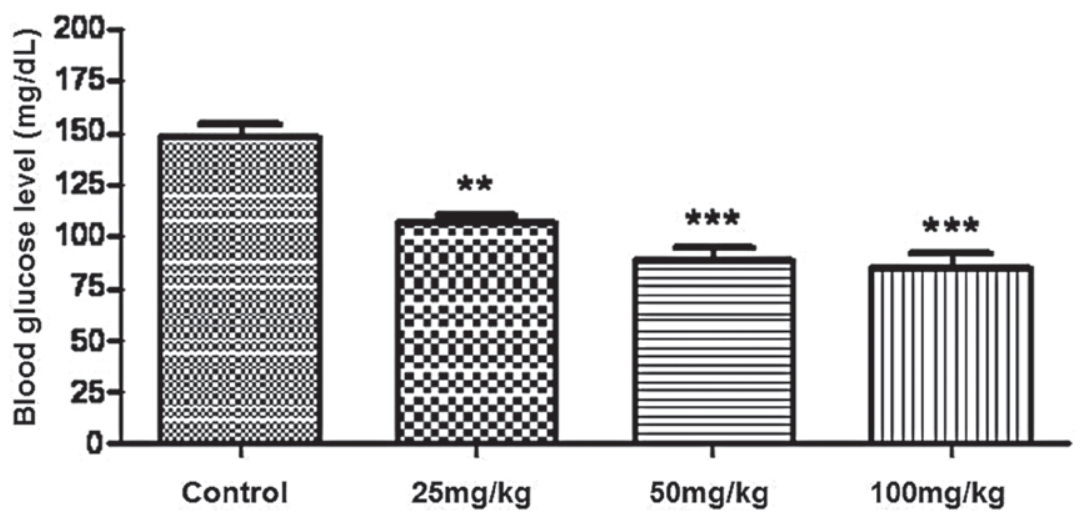

Figure 2 - The effect of administration of stem bark aqueous extract from $P$. ramiflora (PrSBAE) for eigth days on blood glucose level in mice. Each column represents mean \pm S.E.M for five mice. ${ }^{*} P<0.05, * * P<0.01, * * * P<0.001$ different from control group.

writhing. Two animals died. In mice that received $5,000 \mathrm{mg} / \mathrm{kg}$ of the extract we observed signals such as hypnosis, dyspnea. One animal died. When mice were treated orally and intraperitoneal with $100 \mathrm{mg} / \mathrm{kg}$ of the PrSBAE dose, they did not show any toxicity effect.

Weight and blood glucose level in mice treated with 25,50 and $100 \mathrm{mg} / \mathrm{kg}$ of the PrSBAE extract are shown in figures 1 and 2. All administrated doses have shown a significant effect on weight loss when compared to the control group after eight days of treatment. Animals that received 50 and $100 \mathrm{mg} /$ $\mathrm{kg}$ of extracts showed a significant reduction of the levels of blood glucose when compared to the control group. Mice treated with acarbose, a competitive inhibitor of intestinal alpha-glucosidases that slows the breakdown of sucrose and starch (Santeusanio and Compagnucci 1994), were not effective to reduce blood glucose level when compared with polyphenolic enriched crude plant extract after 30 min of treatment (Mai and Chuyen 2007). A previous study of our laboratory (Deconte et al. 2011) conducted in rats treated by 20 days with acarbose did not reveal difference of weight gain and glycemic level of non-diabetic and diabetic groups when compared with the respective controls. Heo et 
al. (2009) showed that diphlorethohydroxycarmalol, isolated from Ishige okamurae, had inhibitory effects on alpha-glucosidase and alpha-amylase activities higher than those of acarbose. Therefore, our results showed that the $P$. ramiflora extracts were more effective to inhibit the activity of alpha-amylase in vitro than acarbose. The in vivo results suggest that PrSBAE reduction of glucose level of treated mice may be due to inhibition of carbohydratehydrolyzing enzymes.

Several plant extracts have high concentrations of tannins, that are compounds that may exert an anti-nutritional effect by interfering with gut function (Carbonaro et al. 2001) and reduce the glycemic response to carbohydrate foods in humans (Gin et al. 1999). In another study, it was investigated whether blood glucose reduction was due to reduced food intake in mice treated with the Syzygium cumini ethanol extract and tannic acid (Oliveira et al. 2005). In the study by Oliveira et al., it was hypothesized that polyphenolic compounds contribute to the reduction of food intake, body weight and the levels of blood glucose. Hence, we cannot exclude the possibility that the $P$. ramiflora extract may contain phenolic compounds and that its effects on weight reduction and the decrease in blood glucose are related to the dietary restriction associated with the inhibition of alpha-amylase.

In conclusion, the present study showed that M. guianensis, S. lethalis, P. torta and P. ramiflora inhibit alpha-amylase activity in vitro even at low concentrations. In addition, $P$. ramiflora bears positive effects on body weight and blood glucose levels.

\section{ACKNOWLEDGMENTS}

Grants to FSE from Fundação de Amparo à Pesquisa do Estado de Minas Gerais (FAPEMIG, $\mathrm{MG}$, Brasil). Fellowships to NMG from Coordenação de Aperfeiçoamento de Pessoal de Nível Superior (CAPES, Brasil). We also thank Dr. Jose Elias de Paula (Botanical Garden of UnB) and
Dra. Ana Angelica Almeida Barbosa (Botanical Garden of UFU) for approving the authenticity of the plants used in the research, and Dr. Paulo S. Pereira and Dra. Suzelei C. França (Department of Biotechnologyt, Ribeirao Preto University, UNAERP, Brazil) for their provision of TLC and HPLC preliminary phytochemical analysis.

\section{RESUMO}

Neste estudo, extratos de espécies de plantas do bioma Cerrado foram avaliados em busca de um potencial inibidor da enzima alfa-amilase salivar humana. As plantas foram coletadas e os extratos obtidos das folhas, da casca e da raiz. Nós realizamos uma análise fitoquímica preliminar e uma triagem destas plantas utilizando um ensaio de inibição da alfa-amilase salivar. Inicialmente, somente três famílias botânicas (Sapotaceae, Sapindaceae e Flacourtiaceae) e 16 extratos apresentaram inibição da alfa-amilase maior que $75 \%$ sendo que os extratos etanólicos da casca do caule e da raiz de Pouteria ramiflora tiveram mais de $95 \%$ de inibição para a concentração final de $20 \mu \mathrm{g} /$ $\mathrm{mL}$. Assim, camundongos Swiss adultos machos foram oralmente tratados com extrato aquoso de P. ramiflora para avaliar a toxicidade aguda e o controle glicêmico. A administração diária do extrato de $P$. ramiflora nas doses de 25, 50 e $100 \mathrm{mg} / \mathrm{kg}$, por oito dias, foi capaz de reduzir o peso corporal e o nível glicêmico nos animais. Esses dados sugerem que o extrato polar de P. ramiflora diminui a atividade amilolítica da saliva, além disso, reduz os níveis de glicose sanguínea.

Palavras-chave: inibição da alfa-amilase, hipoglicemiante, Pouteria ramiflora, Sapotaceae.

\section{REFERENCES}

Ali H, Houghton PJ And Soumyanath A. 2006. AlphaAmylase inhibitory activity of some Malaysian plants used to treat diabetes; with particular reference to Phyllanthus amarus. J Ethnopharmacol 107: 449-455.

ARdon A AND NAKANO T. 1973. Triterpenes from the bark of Pouteria caimito. Planta Med 23: 348-352.

BRAYER GD, LUO Y AND WITHERS SG. 1995. The structure of human pancreatic alpha-amylase at $1.8 \mathrm{~A}$ resolution and comparisons with related enzymes. Protein Sci 4: 17301742 . 
BRITO AS. 1994. Manual de ensaios toxicológicos in vivo, Campinas: Editora da UNICAMP, 122 p.

CARAWAY WT. 1959. A stable starch substrate for the determination of amylase in serum and other body fluids. Am $\mathrm{J}$ Clin Pathol 32: 97-99.

CARbonaro M, Grant G AND PuszTai A. 2001. Evaluation of polyphenol bioavailability in rat small intestine. Eur $\mathrm{J}$ Nutr 40: 84-90.

CONFORTI F, LOIZZO MR, STATTI GA AND MENiCHINI F. 2005. Comparative radical scavenging and antidiabetic activities of methanolic extract and fractions from Achillea ligustica ALL. Biol Pharm Bull 28: 1791-1794.

DE MESQUiTA ML ET AL. 2009. Cytotoxic activity of Brazilian Cerrado plants used in traditional medicine against cancer cell lines. J Ethnopharmacol 123: 439-445.

De Souza PM, de Sales PM, Simeoni LA, Silva EC, Silveira D AND DE Oliveira Magalhaes P. 2012. Inhibitory Activity of alpha-Amylase and alphaGlucosidase by Plant Extracts from the Brazilian Cerrado. Planta Med 78: 393-399.

DECONTE SR, Oliveira RJ, CALÁBria LK, OliVEIRA VN, GOUVEIA NM, MORAES AdA S AND EsPINDOLA FS. 2011. Alterations of antioxidant biomarkers and type I collagen deposition in the parotid gland of streptozotocin-induced diabetic rats. Arch Oral Biol 56: 744-751.

Flausino JO ET AL. 2009. Protease inhibition activity of extracts from Salicaceae species from Brazilian cerrado and Atlantic rain forest and an enriched fraction of clerodane diterpenes (casearins). Rev Bras Farmacogn 19: 755-758.

FUNKE I AND MELZIG MF. 2006. Traditionally used plants in diabetes therapy - phytotherapeutics as inhibitors of $\alpha$-amylase activity. Rev Bras Farmacogn 16: 1-5.

GAD MZ, El-SAWALHI MM, ISMAIL MF AND EL-TANBOULY ND. 2006. Biochemical study of the anti-diabetic action of the Egyptian plants fenugreek and balanites. Mol Cell Biochem 281: 173-183.

Gin H, Rigalleau V, Caubet O, Masquelier J and AUBERTIN J. 1999. Effects of red wine, tannic acid, or ethanol on glucose tolerance in non-insulin-dependent diabetic patients and on starch digestibility in vitro. Metabolism 48: 1179-1183.

HeO SJ, Hwang JY, ChOI JI, HAN JS, KIM HJ AND JEON YJ 2009. Diphlorethohydroxycarmalol isolated from Ishige okamurae, a brown algae, a potent alpha-glucosidase and alpha-amylase inhibitor, alleviates postprandial hyperglycemia in diabetic mice. Eur J Pharmacol 615: 252-256.

Kandra L, Gyemant G, Zajacz A And Batta G. 2004. Inhibitory effects of tannin on human salivary alphaamylase. Biochem Biophys Res Commun 319: 1265-1271.

KIM YM, JeONG YK, WANG MH, LEE WY AND RHEE HI. 2005. Inhibitory effect of pine extract on alpha-glucosidase activity and postprandial hyperglycemia. Nutrition 21: 756-761.

MA J, YANG H, BAsILE MJ AND KenNELly EJ. 2004. Analysis of polyphenolic antioxidants from the fruits of three pouteria species by selected ion monitoring liquid chromatography-mass spectrometry. J Agric Food Chem 52: $5873-5878$.
MAI TT AND CHUYEN NV. 2007. Anti-hyperglycemic activity of an aqueous extract from flower buds of Cleistocalyx operculatus (Roxb.) Merr and Perry. Biosci Biotechnol Biochem 71: 69-76.

MARLES R AND FARNSWORTH NR. 1994. Economic and medicinal plant research. In: WAGNER H AND FARNSWORTH NR (Eds), Plants as sources of antidiabetic agents: Academic Press Ltd., p. 149-187.

McDougall GJ, Dobson P, SMith P, Blake A AND STEWART D. 2005. Assessing potential bioavailability of raspberry anthocyanins using an in vitro digestion system. J Agric Food Chem 53: 5896-5904.

Mesquita ML, Desrivot J, Bories C, Fournet A, Paula JE, GRELLIER P AND ESPINDOLA LS. 2005. Antileishmanial and trypanocidal activity of Brazilian Cerrado plants. Mem Inst Oswaldo Cruz 100: 783-787.

Napolitano DR, Mineo JR, De Souza MA, De Paula JE, ESPINDOLA LS AND ESPINDOLA FS. 2005. Downmodulation of nitric oxide production in murine macrophages treated with crude plant extracts from the Brazilian Cerrado. J Ethnopharmacol 99: 37-41.

NAVAZESH M. 1993. Methods for collecting saliva. Ann N Y Acad Sci 694: 72-77.

Oliveira AC, ENDringer DC, AMORIM LA, DAS GRACAS LBM AND COELHO MM. 2005. Effect of the extracts and fractions of Baccharis trimera and Syzygium cumini on glycaemia of diabetic and non-diabetic mice. J Ethnopharmacol 102: 465-469.

Pellicciari R, ARdon A AND BellaVita V. 1972. Triterpenes from Pouteria caimito. Planta Med 22: 196-200.

Ramasubbu N, Ragunath C And Mishra PJ. 2003. Probing the role of a mobile loop in substrate binding and enzyme activity of human salivary amylase. J Mol Biol 325: 10611076.

Rodrigues AM, De Paula JE, Degallier N, Molez JE AND ESPINDOLA LS. 2006. Larvicidal activity of some Cerrado plant extracts against Aedes aegypti. J Am Mosq Control Assoc 22: 314-317.

SANTEUSANIO F AND COMPAGNUCCI P. 1994. A risk-benefit appraisal of acarbose in the management of non-insulindependent diabetes mellitus. Drug Saf 11: 432-444.

ShU XS, LV JH, TaO J, Li GM, Li HD AND MA N. 2009 Antihyperglycemic effects of total flavonoids from Polygonatum odoratum in STZ and alloxan-induced diabetic rats. J Ethnopharmacol 124: 539-543.

Silva DP, CASAdo-Filho EL, CORRÊA AS, FARIAS LR, Bloch C JR, De SA MF, MENDES PA, Quirino BF, NORONHA EF AND FRANCO OL. 2007. Identification of an alpha-amylase inhibitor from Pterodon pubescens with ability to inhibit cowpea weevil digestive enzymes. J Agric Food Chem 55: 4382-4387.

Silva EM, VALENCIA A, Grossi-De-SÁ MF, ROCHA TL, FreIRE E, PAULA JE AND ESPINDOLA LS. 2009. Inhibitory action of Cerrado plants against mammalian and insect $\alpha$-amylases. J Pestic Biochem Physiol 95: 141-146. 